\title{
Kebijakan exit strategy mengatasi kenaikan harga BBM
}

\author{
Exit strategy overcoming policy rise in fuel prices
}

\author{
Sudarso \\ Departemen Sosiologi , Fakultas Ilmu Sosial dan Ilmu Politik, Universitas Airlangga \\ E-mail: sudarso@fisip.unair.ac.id
}

\begin{abstract}
Abstrak
Di Indonesia, setiap pemerintah mengumumkan kenaikan harga BBM, maka diperkirakan jutaan penduduk menjadi lebih miskin atau jatuh miskin. Penduduk yang sebelumnya masuk kategori near poor, biasanya dengan cepat turun status menjadi orang miskin baru gara-gara kenaikan harga BBM. Penelitian ini bertujuan untuk mengkaji dampak sosial-ekonomi kenaikan BBM terhadap kelangsungan hidup dan mekanisme survival keluarga miskin di Jawa Timur. Studi ini penting dilakukan agar nantinya dapat dirumuskan program-program exit strategy yang benar-benar tepat. Ada beberapa metode yaitu, Pertama, mengkaji dan menganilisis data sekunder. Kedua, melakukan review terhadap hasil-hasil studi. Ketiga, melakukan survey dan penggalian data primer ke lapangan untuk memperoleh gambaran yang valid dan akurat mengenai kondisi terbaru dan berbagai tekanan yang dihadapi keluarga miskin di Provinsi Jawa Timur Keempat, dari 600 keluarga miskin yang diteliti, dalam studi ini kemudian dipilih 30 keluarga miskin yang telah dicoba diwawancarai secara mendalam (indepth interview). Hasil dari penelitian ini adalah upaya kebijakan exit strategy untuk mengatasi kenaikan harga BBM bagi kalangan penduduk miskin. Exit strategy ini mendorong pengembangan ekonomi pedesaan dan sektor pertanian agar tetap dapat menjadi tempat bersandar bagi keluarga miskin meski terkena imbas efek domino kenaikan harga BBM
\end{abstract}

Kata kunci: pemerintah; harga; kebutuhan; miskin; kebijakan

\begin{abstract}
In Indonesia, every government announces an increase in fuel prices, it is estimated that millions of people are poorer or poorer. Residents who were previously categorized as near poor, usually quickly go down to becoming poor people just because of rising fuel prices. This study aims to examine the socio-economic impact of rising fuel prices on the survival and survival mechanisms of poor families in East Java. This study is important so that later exit strategies programs can be formulated that are truly appropriate. There are several methods, namely, First, review and analyze secondary data. Second, review the study results. Third, conducting surveys and extracting primary data to the field to obtain a valid and accurate picture of the latest conditions and various pressures faced by poor families in the Province of East Java. Fourth, out of 600 poor families studied, in this study 30 poor families were selected. try to be interviewed in depth (indepth interview). The results of this study are an exit strategy policy effort to address rising fuel prices for the poor. This exit strategy encourages the development of the rural economy and the agricultural sector so that it can remain a leaning place for poor families despite the impact of the domino effect of rising fuel prices.
\end{abstract}

Keywords: government; price; needs; poor; policy

\section{Pendahuluan}

Kebijakan subsidi BBM merupakan komponen penting guna pemerataan penggunaan energi pada masyarakat khususnya masyarakat kelas menengah ke bawah yang diberlakukan pada saat harga suatu produk energi dinilai tidak sebanding dengan daya beli masyarakat terutama masyarakat yang memiliki pendapatan rendah (Yusgiantoro, 2000).

Meski beresiko memperoleh tantangan dan kecaman dari berbagai pihak, pemerintah akhirnya memutuskan mencabut subsidi BBM dan akan mematok harga BBM sesuai dengan perkembangan harga pasar. Ketika APBN terancam jebol dan anggaran pembangunan berkurang drastis gara-gara subsidi BBM yang terus membengkak, memang tidak banyak pilihan yang bisa dilakukan pemerintah di era Jokowi-JK. 
Seperti diketahui, selama ini subsidi BBM dari tahun 2010-2014 naik rata-rata 31,5\% per tahun di mana jika pada tahun 2010 hanya 82,4 triliun, maka di tahun 2014 telah melonjak menjadi 246,5 triliun rupiah. Dengan kemampuan APBN yang terbatas, sudah barang tentu pembengkakan subsidi BBM sebesar ini membuat ruang gerak untuk memenuhi janji-janji politik Jokowi-JK menjadi terbatas, karena sebagian dari program prioritasnya niscaya tidak akan memperoleh dukungan dana yang cukup.

Di tahun 2015 ini, jika subsidi BBM tidak dikurangi, itu berarti dana APBN yang harus disediakan untuk pos ini adalah 291,1 triliun rupiah. Kebutuhan dan tekanan subsidi BBM yang terlampau besar ini tentu akan menyebabkan ruang fiskal pada APBN 2015 menjadi makin sempit dan target untuk mendongkrak pertumbuhan ekonomi hingga 7 persen niscaya akan sulit tercapai.

Hingga akhir masa jabatannya, SBY-Boediono kita tahu memilih tidak mengeluarkan kebijakan untuk mengurangi subsidi BBM. Kekhawatiran pengurangan subsidi BBM akan melahirkan efek domino yang kontra-produktif, seperti inflasi, penciptaan lapangan kerja menjadi stagnan dan lain sebagainya, seringkali menjadi alasan kenapa keputusan untuk menaikkan harga BBM selalu menjadi alternatif pilihan yang terakhir pemerintah. Sebagai Presiden dan Wakil Presiden terpilih, bola panas mau tidak mau memang ada di tangan Jokowi-JK, dan keputusan untuk menaikan harga BBM akhirnya telah dilakukan --meski kemudian karena alasan terjadi penurunan harga minyak dunia, akhirnya harga BBM diturunkan kembali.

Penerapan kebijkan pemerintah berkaitan erat dengan masalah sosial seputar pelaksaan program atau kebijakan, administrasi, maupun usaha guna memberikan efek tertentu dari program atau kebijakan tersebut kepada masyarakat (Suwitri, 2008 : 80). Di lapangan, keputusan pemerintah yang sempat menurunkan kembali harga BBM tentu melegakan masyarakat. Namun demikian, ketika harga BBM kembali diturunkan, ternyata hal itu tidak otomatis diikuti dengan terjadinya penurunan kembali tarif berbagai barang dan jasa di masyarakat yang sudah terlanjur terkerek naik. Bahkan, ketika penurunan harga BBM terjadi tidak dalam waktu yang lama, karena kemudian naik lagi, maka harga-harga berbagai barang kebutuhan masyarakat pun sepertinya naik terus.

Tanggal 28 Maret 2015, pemerintah melalui keputusan Menteri ESDM Nomor 4 Tahun 2015 tentang Perhitungan Harga Jual Eceran Bahan Bakar kembali menaikan harga BBM. Keputusan ini diambil untuk menjaga kestabilan perekonomian nasional serta menjamin ketersediaan BBM secara nasional. Pemerintah memutuskan BBM jenis Premium dan solar bersubsidi di wilayah penugasan luar JawaMadura-Bali mengalami kenaikan harga, masing-masing sebesar Rp 500 per liter. Sedangkan harga minyak tanah dinyatakan tetap, yaitu Rp 2.500 per liter. Artinya, di masyarakat kini harga solar menjadi Rp 6.900 per liter, sementara Premium Rp 7.300 per liter. Ekonom Enny Sri Hartati mengatakan kenaikan harga BBM ini tentu akan mempengaruhi inflasi serta daya beli masyarakat Indonesia yang tengah mengalami banyak guncangan ekonomi.

Hasil penelitian terdahulu mengenai pemberian Bantuan Langsung Tunai (BLT) terhadap konsekuensi dari kenaikan BBM menunjukkan bahwa bantuan langsung tunai dan atau sementara kepada masyarakat sebagai kompensasi atas kenaikan harga BBM menyebabkan meningkatnya penduduk miskin dan penerapannya pun belum efektif, yang berarti pembagian BLT/BLSM masih terdapat masalah, terutama ketidaktepatan bantuan kepada rumah tangga sasaran (penduduk miskin) dan masih belum terorganisirnya kelembagaan yang ditunjuk ketika membagikan BLT/BLSM (Hasyim 2005; Iqbal, 2008; SMERU 2011; Junaidi, 2013; Alliyah, 2013).

Pilihan berbagai kebijakan dalam mengantisipasi dampak kenaikan harga BBM pada usaha antara lain yakni kebijakan dari pemerintah dapat berperan serta guna menjamin dan melakukan monitoring BBM subsidi terdistribusi dengan baik kepada nelayan-nelayan kecil dan menentukan harga produk perikanan yang pro rakyat dengan harapan pelaku usaha perikanan dapat mencapai keuntungan yang layak dan harga stabil perlu diupayakan dalam aspek peningkatan kesejahteraan rumah tangga perikanan (Suryawati, 2013). 
Kebijakan yang dapat dilakukan pemerintah terkait upaya antisipasi kenaikan harga BBM atau penyaluran BBM bersubsidi antara lain: (1) Membangun lembaga kredit yang dimaksudkan untuk meningkatkan modal usaha melalui lembaga keuangan yang sudah terbentuk di masyarakat, seperti koperasi; (2) mengembangkan diversifikasi usaha; dan (3) mengupayakan rasionalisasi artifisial, yakni pemerintah mengalokasikan dana dengan mengalihkan kegiatan yang tidak efisien ke aktivitas ekonomi yang lebih menguntungkan (Fauziyah, 2003; Pasaribu, 2008).

Bukti-bukti di lapangan telah banyak memperlihatkan, bahwa meski subsidi BBM tidak jadi dikurangi, tetapi ancaman inflasi tetap terjadi, yang ujung-ujungnya menyebabkan beban yang ditanggung masyarakat menjadi lebih berat. Kenaikan harga BBM yang terjadi sebelumnya, ditengarai telah melahirkan efek domino yang membuat posisi masyarakat miskin menjadi makin rentan karena harus menghadapi tekanan kebutuhan hidup sehari-hari yang makin berat. Bukan tidak mungkin masyarakat miskin akan menjadi korban pertama yang paling menderita pasca kenaikan harga BBM, karena mereka masuk dalam proses pendalaman kemiskinan.

Seperti diketahui, sekitar $70 \%$ pengeluaran keluarga-keluarga miskin biasanya adakan untuk kebutuhan konsumsi, dan kenaikan harga BBM biasanya dengan cepat akan diikuti oleh kenaikan harga kebutuhan hidup sehari-hari yang terkena imbas psikologis kenaikan harga BBM. Sementara itu, bagi masyarakat miskin yang menjadi pelaku UMKM, kenaikan harga BBM ditengarai juga akan menyebabkan terjadinya proses pengikisan modal usaha, karena makin mengecilnya margin keuntungan yang diterima mereka. Setiap terjadi kenaikan harga BBM, masyarakat miskin biasanya akan dihadapkan pada dilema yang berat: apakah mereka harus ikut menaikan komoditi yang dihasilkan dengan resiko pembeli menjadi berkurang ataukah bertahan dengan harga jual yang lama, tetapi beresiko margin keuntungan menjadi lebih tipis.

Di Indonesia, setiap pemerintah mengumumkan kenaikan harga BBM, maka diperkirakan jutaan penduduk menjadi lebih miskin atau jatuh miskin. Penduduk yang sebelumnya masuk kategori near poor, biasanya dengan cepat turun status menjadi orang miskin baru gara-gara kenaikan harga BBM. Pada tahun 2005, misalnya ketika kenaikan harga BBM terjadi dua kali bertutut-turut, dilaporkan dampaknya telah memacu terjadinya inflasi tahunan hingga 17,11\%, dan akibatnya adalah sekitar 4 juta lebih penduduk Indonesia di berbagai daerah jatuh miskin sepanjang Februari 2005-Maret 2006.

Bagi Jokowi-JK, keputusan untuk menaikan harga BBM barangkali memang merupakan pertaruhan politik yang sangat besar. Tetapi, hingga saat ini harus diakui dukungan dan harapan publik kepada Jokowi-JK sangatlah besar. Momentum dan tingginya kepercayaan publik kepada Jokowi-JK ini, jika dibuktikan dengan keberanian plus program alih subsidi BBM yang benar-benar tepat, maka bukan tidak mungkin keputusan yang tidak populis untuk menaikan harga BBM justru akan menjadi batu loncatan mengembangkan program-program lain untuk memenuhi janji politik mereka.

Dengan program dan mekanisme pemberian kompensasi yang tepat sasaran serta kemampuan untuk menjaga agar inflasi tidak menggerus daya tahan keluarga miskin, niscaya dampak kenaikan harga BBM akan bisa ditekan hingga ke tingkat yang minimal. Di samping itu, bukan tidak mungkin, kebijakan penghapusan subsidi BBM nantinya justru akan berdampak positif mendorong penciptaan lapangan kerja dan penurunan angka kemiskinan melalui stimulan program kompensasi yang tepat sasaran. Cuma, yang menjadi masalah, seberapa jauh kadar keberdayaan dan kekenyalan keluarga miskin untuk menahan imbas atau dampak kenaikan BBM nantinya? Studi ini berupaya untuk mengkaji dampak sosial-ekonomi kenaikan BBM terhadap kelangsungan hidup dan mekanisme survival keluarga miskin di Jawa Timur. Studi ini penting dilakukan agar nantinya dapat dirumuskan program-program exit strategy yang benar-benar tepat.

\section{Metode Penelitian}

Kegiatan ini pada dasarnya bukan hanya bermaksud mengkaji situasi problematik yang dihadapi keluarga miskin pasca kenaikan harga BBM, tetapi juga mencoba merumuskan implementasi 
kebijakan pro poor yang benar-benar kontekstual dan sesuai kebutuhan masyarakat miskin, khususnya di Provinsi Jawa Timur. Untuk memperoleh masukan dan data yang akurat, dalam kegiatan ini bahan-bahan yang dibutuhkan telah dikumpulkan melalui beberapa cara, yakni: Pertama, mengkaji dan menganilisis data sekunder terbaru mengenai kondisi kemiskinan dan kondisi demografis penduduk Provinsi Jawa Timur. Data sekunder yang dibutuhkan dicari dari BPS, survei-survei lokal, dan data dari berbagai perguruan tinggi dan lembaga penelitian lainnya.

Tabel 1.

Lokasi dan Jumlah Responden

\begin{tabular}{|c|c|c|c|}
\hline Kota/Kabupaten & Kecamatan & Desa/Kelurahan & $\begin{array}{c}\text { Jumlah } \\
\text { Responden }\end{array}$ \\
\hline \multirow{3}{*}{ Kota Malang } & Kecamatan Lowokwaru & Kelurahan Tlogomas & 50 \\
\hline & Kecamatan Klojen & Kelurahan Klojen & 39 \\
\hline & Kecamatan Sukun & Kelurahan Sukun & 11 \\
\hline \multirow{2}{*}{ Kota Kediri } & Kecamatan Pesantren & Kelurahan Burengan & 50 \\
\hline & Kecamatan Mojoroto & Kelurahan Lirboyo & 50 \\
\hline \multirow{2}{*}{ Kota Pasuruan } & Kecamatan Bugul Kidul & Kelurahan Kepel & 50 \\
\hline & Kecamatan Purworejo & $\begin{array}{c}\text { Kelurahan } \\
\text { Ngemplakrejo }\end{array}$ & 50 \\
\hline \multirow{2}{*}{ Kabupaten Sampang } & Kecamatan Camplong & $\begin{array}{l}\text { Kelurahan Dharma } \\
\text { Camplong }\end{array}$ & 50 \\
\hline & Kecamatan Sampang & Kelurahan Baruh & 50 \\
\hline \multirow{2}{*}{ Kabupaten Tuban } & Kecamatan Kerek & Kelurahan Margorejo & 50 \\
\hline & Kecamatan Tuban & Kelurahan Karangsari & 50 \\
\hline \multirow[t]{2}{*}{ Kabupaten Nganjuk } & Kecamatan Sukomoro & Kelurahan Ngrami & 50 \\
\hline & $\begin{array}{c}\text { Kecamatan Rejoso } \\
\text { Jumlah }\end{array}$ & Kelurahan Sidokare & $\begin{array}{c}50 \\
600 \\
\end{array}$ \\
\hline
\end{tabular}

Sumber: Data Primer

Uraian tentang kondisi umum kemiskinan di Povinsi Jawa Timur ini penting untuk mengetahui peta makro permasalahan kemiskinan, dinamika dan persebaran penduduk miskin di Provinsi Jawa Timur. Kedua, melakukan review terhadap hasil-hasil studi mengenai masyarakat miskin dan kemiskinan di Provinsi Jawa Timur dan efektivitas pelaksanaan program penanggulangan kemiskinan yang telah dilakukan oleh peneliti sebelumnya. Review terhadap hasil penelitian ini dibatasi hanya pada hasil penelitian terbaru yang relevan. Tujuan dilakukan review terhadap hasil studi tentang kemiskinan ini adalah untuk memperoleh kerangka acuan dan kerangka analisis dalam rangka memahami secara teoritik berbagai faktor penyebab kemiskinan yang dialami masyarakat.

Ketiga, melakukan survey dan penggalian data primer ke lapangan untuk memperoleh gambaran yang valid dan akurat mengenai kondisi terbaru dan berbagai tekanan yang dihadapi keluarga miskin di Provinsi Jawa Timur. Data primer ini, digali dari masyarakat atau tepatnya keluarga-keluarga miskin yang ada di lokasi penelitian. Jumlah keluarga miskin yang menjadi responden, ditetapkan sebanyak 600 keluarga miskin. Penelitian lapangan dilakukan di 6 kota/kabupaten, yaitu: Kota Malang, Kota 
Kediri, Kota Pasuruan, Kabupaten Sampang, Kabupaten Tuban, dan Kabupaten Nganjuk. Di masingmasing kota/kabupaten jumlah keluarga miskin yang diteliti ditetapkan sebanyak 100 keluarga miskin. Sebagaimana tertera pada tabel 1.

Keempat, dari 600 keluarga miskin yang diteliti, dalam studi ini kemudian dipilih 30 keluarga miskin yang telah dicoba diwawancarai secara mendalam (indepth interview), terutama menyangkut berbagai tekanan kemiskinan yang dialami pasca kenaikan harga BBM, dan mekanisme survival yang dikembangkan untuk menyiasati perubahan situasi yang menjejas mereka. In-depth interview dilakukan dengan mendasarkan pada interview guide yang telah dipersiapkan sebelumnya. Dengan melakukan wawancara secara mendalam ini, bukan saja dapat diperoleh pengalaman langsung keluarga miskin menyiasati keadaan, tetapi juga dampak yang mereka alami akibat terjadinya kenaikkan harga kebutuhan pokok di pasar.

Seluruh data yang berhasil dikumpulkan, telah diolah dan dipadukan antara data kuantitatif dan data kualitatif yang diperoleh dari hasil in-depth interview. Di hasil akhir laporan, selain dirumuskan kembali temuan-temuan pokok hasil studi dan sejumlah rekomendasi, juga diketengahkan rencana aksi yang dapat menjadi acuan bagi Pemerintah Provinsi Jawa Timur dalam merumuskan exit strategy untuk membantu keluarga miskin yang terkena dampak kenaikan harga BBM.

\section{Hasil dan Pembahasan}

\section{Exit strategy pasca kenaikan harga BBM: Sejumlah rekomendasi}

Kebijakan exit strategy seperti apakah yang seharusnya dikembangkan untuk mencegah agar keluarga miskin tidak makin terpuruk karena imbas "efek domino" kenaikan harga BBM? Untuk menjawab pertanyaan ini harus diakui bukanlah hal yang mudah, karena tekanan kemiskinan akibat kenaikan harga kebutuhan hidup sehari-hari dan kelangsungan usaha yang ditekuni masyarakat miskin seringkali makin berat pasca terjadinya kenaikan harga BBM.

Kajian sebagaimana dilaporkan telah mengajarkan bahwa upaya untuk melindungi keluarga miskin dari tekanan kebutuhan hidup pasca kenaikan harga BBM dan bagaimana pula menjamin agar kegiatan usaha yang ditekuni keluarga miskin tidak terkena dampak kenaikan harga bahan baku dan biaya produksi, membutuhkan lebih dari sekadar program intervensi yang sifatnya karitatif. Untuk memastikan agar keluarga-keluarga miskin di berbagai kabupaten/kota di Provinsi Jawa Timur tidak digerus imbas kenaikan harga BBM, sesungguhnya yang dibutuhkan bukan hanya memberi bantuan sembako, bantuan BLT, dan upaya pengembangan kegiatan produkif keluarga miskin atau bagaimana meningkatkan produktivitas kerja masyarakat miskin, tetapi juga menyangkut pada persoalan bagaimana upaya pemberdayaan yang dilakukan dapat menjamin para keluarga miskin memperoleh apa yang sebetulnya menjadi hak mereka, khususnya yang berkaitan pembagian margin keuntungan yang lebih adil dan proporsional.

Berdasarkan data yang diperoleh dari lapangan, diketahui bahwa khusus untuk program-program kompensasi kenaikan harga BBM yang cenderung berorientasi pada pemenuhan kebutuhan dasar masyarakat miskin, atau program-program yang hanya berdasarkan pada pertimbangan logika produksi atau sekadar mengejar peningkatan omzet produksi, bukan saja menyebabkan terjadinya overs stock dan memaksa masyarakat miskin harus berhadapan dengan keterbatasan pangsa pasar. Tetapi, juga melahirkan proses marginalisasi dan ketergantungan penduduk miskin, terutama penduduk miskin yang mengalami proses pendalaman kemiskinan. Kelompok masyarakat miskin yang ada di berbagai wilayah kota/kabupaten di Jawa Timur, seperti pekerja di sektor informal, pedagang tradisional, pekerja serabutan, petani dan nelayan miskin, dan sejenisnya mereka umumnya rawan tersisih, rawan diperlakukan salah, dan sulit dapat melakukan mobilitas vertikal karena struktur sosial yang ada makin hari terasa makin tidak ramah (rigid). Tidak banyak celah atau peluang berusaha dan peluang sosial yang bisa diakses keluarga miskin, sehingga kesempatan mereka untuk melakukan perbaikan taraf hidup seringkali terhambat, bahkan menemui jalan buntu. 
Kajian ini, pada batas-batas tertentu menemukan bahwa berbagai program kompensasi kenaikan harga BBM yang digulirkan --terutama dalam bentuk pemberian subsidi yang karitatif dan bantuan modal usaha atau pembinaan usaha produktif keluarga miskin-- seringkali masih terkonsentrasi pada rekayasa yang sifatnya teknis produksi dan cenderung hanya beriorientasi pada peningkatan kuantitas produk yang dihasilkan keluarga miskin, sehingga dalam banyak hal lebih menguntungkan kelompok masyarakat yang memiliki modal dan asset produksi yang berlebih. Sebuah keluarga miskin yang memiliki usaha kecil, kemudian berkat bantuan modal pedagang perantara atau tengkulak dapat menghasilkan produk yang lebih banyak, sering yang terjadi mereka tetap memperoleh margin keuntungan yang terbatas, sementara di pihak lain justru para tengkulak dan pedagang perantara itu yang bisa memetik margin keuntungan yang lebih besar.

Banyak kajian telah membuktikan bahwa program pembangunan yang digulirkan pasca kenaikan harga BBM dan berbagai program penanggulangan kemiskinan yang dikembangkan seringkali kurang memperhatikan karakteristik dan konteks lokal masyarakat miskin, sehingga jangan heran jika yang terjadi kemudian adalah paket-paket kebijakan dan program yang bersifat meritokratis. Bisa dibayangkan, apa yang terjadi jika pemerintah mengucurkan sejumlah dana kepada masyarakat miskin tanpa terlebih dahulu mempertimbangkan struktur sosial di masyarakat lokal yang terpolarisasi atau paling-tidak terstratifikasi atas dasar berbagai demensi? Mungkinkah yang namanya pedagang kecil-kecilan dengan latar belakang pendidikan yang rendah dapat mengembangkan usahanya dan menembus pasar yng lebih luas, sementara di saat yang sama supermarket mini semacam Indomaret, Alfamart, dan sebagainya masuk ke kampung-kampung dan kompleks perumahan? Mungkinkah, anggota masyarakat miskin di lapisan yang paling miskin bisa memperoleh kesempatan memberdayakan dirinya, jika cara pandang terhadap mereka masih dipenuhi berbagai syakwasangka?

Kedepan, untuk mencegah agak tidak lagi terperosok pada kekeliruan yang serupa, dan upaya untuk melindungi dan memberdayakan keluarga miskin di Provinsi Jawa Timur pasca kenaikan harga BBM dapat menjadi exit strategy benar-benar efektif, maka yang dibutuhkan bukan sekadar kesediaan untuk melakukan introspeksi, tetapi juga revitalisasi program perlindungan dan pemberdayaan masyarakat miskin yang benar-benar berpihak kepada lapisan yang paling miskin. Dalam upaya merumuskan exit strategy, khususnya program kompensasi kenaikan harga BBM di berbagai kota/kabupaten di Provinsi Jawa Timur, ke depan strategi yang perlu dikembangkan adalah sebagai berikut:

Pertama, untuk mengeliminasi kemungkinan terjadinya bias dalam penentuan kelompok target atau sasaran program penanggulangan kemiskinan pasca kenaikan harga BBM, prasyarat pertama yang dibutuhkan adalah data penduduk dan RT miskin yang benar-benar up to date dan valid. Di berbagai kota/kabupaten di Jawa Timur, akan lebih baik jika tim verifikasi tidak hanya dibentuk di tingkat kabupaten/kota, tetapi justru yang lebih penting adalah tim verifikasi di tingkat desa/kelurahan --yang di dalamnya melibatkan anggota tim verifikasi dari perwakilan Ketua RT/RW, tokoh agama dan tokoh masyarakat, serta perwakilan perempuan. Dengan dilakukan verifikasi terlebih dahulu tentang siapa sebenarnya warga masyarakat yang termasuk benar-benar miskin, maka kemungkinan terjadinya bias pada pemilihan kelompok target sasaran menjadi lebih kecil terjadi.

Kedua, dalam upaya mengurangi atau bahkan mengeliminasi dampak kenaikan harga BBM terhadap kelangsungan usaha yang ditekuni keluarga-keluarga miskin di Provinsi Jawa Timur, salah satu hal yang perlu mendapat perhatian serius adalah berkaitan dengan pilihan arah perkembangan usaha yang seharusnya ditempuh keluarga miskin. Bagi pelaku usaha mikro dan kecil, terutama, untuk mengatasi imbas efek domino kenaikan harga BBM yang biasanya diikuti dengan kenaikan harga bahan baku dan biaya produksi, maka langkah realistis yang mereka lakukan bukanlah bagaimana menawarkan kenaikan harga jual produk atau komoditi yang mereka hasilkan. Melainkan, yang langkah lebih strategis adalah bagaimana mereka bisa menjual komoditi yang dihasilkan dengan harga yang bersaing, tetapi jumlah keuntungan yang diperoleh tidak turun, atau syukur malah naik.

Selama ini, kekurangan pokok yang perlu diperhatikan dari berbagai upaya pengentasan masyarakat miskin yang banyak dipraktikkan adalah bahwa mereka menjadi begitu memusatkan perhatian pada peningkatkan kuantitas produksi atau hasil kegiatan produktif masyarakat miskin, sehingga kebutuhan 
sistem produksi mendapat tempat yang lebih utama daripada kebutuhan masyarakat miskin yang lebih substansial. Hasil kajian sebagaimana dilaporkan telah mengajarkan bahwa untuk lebih menjamin efektivitas pelaksanaan program kompensasi kenaikan harga BBM, maka seyogianya disadari bahwa meningkatkan kesejahteraan penduduk miskin sesungguhnya tidak selalu harus dengan cara memacu perkembangan dan semata hanya berusaha meningkatkan volume atau jumlah produksi sektor usaha kecil tersebut. Sebagai salah satu alternatif dan mungkin juga dapat dilakukan secara bersamaan, pola lain yang dapat dilaksanakan untuk mengembangkan usaha kecil adalah dengan cara melakukan efisiensi proses produksi.

Yang dimaksudkan melakukan efisiensi proses prroduksi di sini adalah bagaimana keluarga miskin yang menjadi pelaku usaha mikro dan kecil dapat menjual komoditi mereka dengan harga tetap meski biaya produksi naik dengan pertimbangan untuk mencuri kesempatan pasca terjadinya kenaikan harga BBM. Dengan melibatkan tenaga kerja dari kalangan angota keluarga sendiri, dan melakukan proses produksi yang benar-benar efisien diharapkan para pelaku usaha mikro dan kecil tetap dapat menjual komoditi yang dihasilkan dengan harga yang relatif tetap, tetapi di saat yang sama keuntungan yang diperoleh tidak berkurang atau bahkan bertambah karena efisiensi yang dilakukan dalam kegiatan produksi.

Ketiga, berkaitan dengan upaya mengurangi kadar kerentanan dan sekaligus bagaimana memperkuat penyangga sosial-ekonomi keluarga miskin agar tidak terperangkap dalam pusaran dan proses pendalaman kemiskinan pasca kenaikan harga BBM. Dalam hal ini, salah satu hal yang dapat dikembangkan adalah bagaimana sejak awal mendorong pengembangan kegiatan produktif alternatif atau deversifikasi usaha keluarga miskin, terutama dengan melibatkan peran aktif kaum perempuan yang berasal dari keluarga miskin.

Pengalaman telah banyak membuktikan bahwa untuk meningkatkan kadar keberdayaan keluarga miskin dan sekaligus mencegah resiko kemungkinan terjadinya kegagalan total dari usaha keluarga miskin alangkah baiknya jika di saat yang bersamaan tiap-tiap anggota keluarga yang termasuk tenaga kerja produktif didorong untuk mengembangkan kegiatan usaha yang beraneka-ragam atau satu dengan yang lain saling berbeda. kajian ini telah membuktikan bahwa sebuah keluarga yang sematamata hanya menggantungkan kepada satu matapencaharian - di mana suami, istri dan anak semua bekerja di sektor yang sama - umumnya secara sosial-ekonomi lebih rapuh karena jika suatu saat harga komoditi yang mereka produksi anjlok, maka itu berarti semua anggota keluarga akan kehilangan dan mengalami kerugian yang sama. Ini berbeda jika dalam sebuah keluarga, masingmasing anggota memiliki matapencaharian yang berbeda-beda.

Keluarga yang mengembangkan pola diversifikasi usaha, terbukti dalam kehidupan sehari-hari mereka selalu lebih berdaya dan kenyal terhadap tekanan kebutuhan ekonomi. Ke depan, dengan memberi kesempatan kepada kaum perempuan atau anggota keluarga lain yang belum bekerja agar dapat memperoleh aset dan peluang untuk mengembangkan diversifikasi usaha, maka kemungkinan untuk menambah tingkat kekenyalan dan daya tahan keluarga miskin niscaya akan makin besar. Bagi masyarakat miskin di Provinsi Jawa Timur, salah satu program strategis yang perlu dikembangkan untuk mempercepat upaya pemberdayaan keluarga miskin adalah memberi paket bantuan modal usaha ganda bagi keluarga miskin, di mana antara laki-laki dan perempuan diberi bantuan modal secara serentak tetapi untuk tujuan pengembangan usaha yang berbeda.

Keempat, kebijakan exit strategy yang perlu dikembangkan menghadapi dampak kenaikan harga BBM adalah bagaimana mendorong pengembangan ekonomi pedesaan dan sektor pertanian agar tetap dapat menjadi tempat bersandar bagi keluarga miskin meski terkena imbas efek domino kenaikan harga BBM. Bantuan dan program yang digulirkan pemerintah di sini seyogianya tidak hanya berupa bantuan modal usaha bagi petani miskin, tetapi yang lebih penting justru adalah bantuan dalam bentuk satuan biaya produksi, seperti pupuk dan bantuan dalam bentuk asset produktif yang bermanfaat memperbesar margin pembangian keuntungan yang mereka peroleh. Kelebihan program penanggulangan berbasis aset adalah bantuan yang disalurkan tidak akan habis, tetapi akan tetap berkelanjutan dan dapat sekaligus memperkuat posisi bargaining penduduk miskin. Program 
penanggulangan kemiskinan yang berbasis pada pemberian bantuan dalam bentuk aset produksi ini sudah barang tentu akan lebih bermakna jika diprioritaskan kepada penduduk miskin yang benarbenar membutuhkan, seperti buruh tani miskin yang tidak/belum memiliki aset produksi sendiri atau bantuan dalam bentuk aset kepada kaum perempuan keluarga tani yang membutuhkannya. Dalam praktik, pemberian bantuan aset produksi bagi keluarga miskin ini bisa dilakukan kepada perseorangan dan kelompok secara kooperatif, yang penting dengan memiliki sendiri aset produksi tertentu, maka diharapkan bukan saja akan meningkatkan posisi bargaining penduduk miskin, tetapi juga meningkatkan margin keuntungan yang bakal mereka peroleh. Di kalangan petani gurem, misalnya, bantuan secara berkelompok dalam bentuk mesin selep padi niscaya akan sangat bermanfaat memfasilitasi petani kecil untuk dapat memperoleh nilai tambah atas produk panenan yang mereka hasilkan.

Kelima, untuk memastikan agar keluarga miskin tidak kolaps pasca terjadinya kenaikan harga BBM, sejak awal perlu disadari pemerintah tentang arti penting program kompensasi kenaikan harga BBM yang benar-benar berorientasi pada pemberdayaan. Program-program penanggulangan kemiskinan yang digulirkan ke masyarakat pasca kenaikan harga BBM seyogianya tidak hanya terjebak pada program-program yang sifatnya karitatif atau darurat-penyelamatan, melainkan harus lebih mengedepankan program-program yang berorientasi pada proses pemberdayaan, yang intinya bersifat people centered, participatory, empowering, dan sustainable.

Tabel 2.

Program Exit Strategy Menghadapi Dampak Kenaikan Harga BBM di Kalangan Keluarga Miskin di Provinsi Jawa Timur

\begin{tabular}{|c|c|c|}
\hline Isu Prioritas & Program & Tujuan \\
\hline $\begin{array}{c}\text { Margin keuntungan yang } \\
\text { diperoleh makin kecil pasca } \\
\text { kenaikan harga BBM, } \\
\text { sehingga terjadi proses } \\
\text { pengikisan modal usaha }\end{array}$ & $\begin{array}{c}\text { Bantuan modal usaha murah } \\
\text { bagi keluarga miskin. } \\
\text { Bantuan aset produksi bagi } \\
\text { pengembangan usaha } \\
\text { keluarga miskin. } \\
\text { Pelatihan manajemen produksi } \\
\text { yang mendukung efisiensi } \\
\text { produksi usaha keluarga } \\
\text { miskin } \\
\text { Bantuan paket modal usaha } \\
\text { ganda bag i keluarga miskin } \\
\text { (ayah-ibu untuk usaha yang } \\
\text { berbeda). } \\
\text { Pelatihan ketrampilan dan } \\
\text { pemberdayaan ibu-ibu dari } \\
\text { keluarga miskin } \\
\text { Pengembangan lembaga } \\
\text { penyangga produk/komoditi } \\
\text { yang dihasilkan keluarga } \\
\text { miskin }\end{array}$ & $\begin{array}{l}\text { Mencegah agar tidak terjadi } \\
\text { pengikisan modal usaha, } \\
\text { dan sekaligus membantu } \\
\text { agar terjadi peningkatan } \\
\text { produktivitas masyarakat } \\
\text { miskin. Meningkatkan kadar } \\
\text { keberdayaan keluarga } \\
\text { miskin, dan meningkatkan } \\
\text { pembagian margin } \\
\text { keuntungan bagi keluarga } \\
\text { miskin. }\end{array}$ \\
\hline $\begin{array}{c}\text { Kondisi sosial-ekonomi } \\
\text { keluarga miskin cenderung } \\
\text { makin sulit pasca kenaikan } \\
\text { harga BBM. Kadar } \\
\text { kerentanan makin rapuh, } \\
\text { utang meningkat, aset } \\
\text { produksi terpaksa dijual, } \\
\text { dan keluarga miskin makin } \\
\text { kesulitan untuk memenuhi } \\
\text { kebutuhan hidup sehari-hari }\end{array}$ & $\begin{array}{c}\text { Bantuan program } \\
\text { penanggulangan kemiskinan } \\
\text { yang bersifat karitatif. } \\
\text { Bantuan cost of living bagi } \\
\text { keluarga miskin di musim } \\
\text { paceklik. }\end{array}$ & $\begin{array}{c}\text { Mengurangi beban tekanan } \\
\text { kemiskinan yang dihadapi } \\
\text { masyarakat miskin }\end{array}$ \\
\hline $\begin{array}{l}\text { Bantuan dari program } \\
\text { kompensasi kenaikan } \\
\text { harga BBM yang banyak } \\
\text { diterima keluarga miskin }\end{array}$ & $\begin{array}{l}\text { Pengembangan program } \\
\text { penanggulangan kemiskinan } \\
\text { yang sifatnya open menu. } \\
\text { Pendampingan proses }\end{array}$ & $\begin{array}{c}\text { Menawarkan pilihan } \\
\text { program bagi masyarakat } \\
\text { miskin secara kontekstual. } \\
\text { Meningkatkan kadar }\end{array}$ \\
\hline
\end{tabular}




\begin{tabular}{|c|c|c|}
\hline $\begin{array}{l}\text { umumnya bersifat karitatif. } \\
\text { Manfaat program } \\
\text { penanggulangan } \\
\text { kemiskinan lebih banyak } \\
\text { sekadar memperpanjang } \\
\text { daya tahan keluarga miskin } \\
\text { dari tekanan kemiskinan } \\
\text { daripada mendukung } \\
\text { meningkatnya keberdayaan } \\
\text { ekonomi keluarga miskin }\end{array}$ & $\begin{array}{c}\text { pemberdayaan keluarga } \\
\text { miskin. } \\
\text { Bantuan berupa aset atau } \\
\text { peralatan produksi bagi } \\
\text { keluarga miskin. }\end{array}$ & $\begin{array}{c}\text { keberdayaan keluarga } \\
\text { miskin. }\end{array}$ \\
\hline $\begin{array}{c}\text { Upaya untuk } \\
\text { mengembangkan } \\
\text { mekanisme subsistensi } \\
\text { cenderung makin sulit, } \\
\text { peran patront juga } \\
\text { memudar dan tidak banyak } \\
\text { penduduk miskin yang } \\
\text { memiliki koneksi yang } \\
\text { dapat dimanfaatkan untuk } \\
\text { mencari pekerjaan atau } \\
\text { tempat meminjam modal } \\
\text { usaha murah }\end{array}$ & $\begin{array}{c}\text { Pengembangan patront, } \\
\text { pranata sosial atau lembaga } \\
\text { subtitutif di tingkat lokal yang } \\
\text { fungsional dalam membantu } \\
\text { dan memberikan perlindungan } \\
\text { sosial bagi masyarakat miskin. }\end{array}$ & $\begin{array}{l}\text { Meningkatkan perlindungan } \\
\text { sosial dan membantu } \\
\text { pengembangan } \\
\text { keberdayaan masyarakat } \\
\text { miskin berbasis dukungan } \\
\text { komunitas lokal (community } \\
\text { support system) }\end{array}$ \\
\hline $\begin{array}{l}\text { Tekanan kebutuhan hidup } \\
\text { seringkali menyebabkan } \\
\text { keluarga miskin terpaksa } \\
\text { mengorbankan kebutuhan } \\
\text { perawatan kesehatan dan } \\
\text { kebutuhan gizi anak }\end{array}$ & $\begin{array}{c}\text { Bantuan program perawatan } \\
\text { kesehatan dan pemenuhan } \\
\text { kebutuhan gizi bagi anak-anak } \\
\text { dan keluarga miskin. }\end{array}$ & $\begin{array}{l}\text { Meningkatkan status gizi } \\
\text { anak dan keluarga miskin }\end{array}$ \\
\hline $\begin{array}{l}\text { Akses ke sumber-sumber } \\
\text { pemasaran relatif rendah, } \\
\text { sehingga ketergantungan } \\
\text { pada peran pedagang } \\
\text { perantara cenderung tinggi }\end{array}$ & $\begin{array}{l}\text { Pembinaan sentra-sentra } \\
\text { usaha masyarakat miskin. } \\
\text { Pelatihan peningkatan } \\
\text { standarisasi produk } \\
\text { masyarakat miskin. } \\
\text { Pengembangan peran } \\
\text { lembaga penampung produk } \\
\text { usaha masyarakat miskin. }\end{array}$ & $\begin{array}{c}\text { Meningkatkan kualitas } \\
\text { produk dan memastikan } \\
\text { pemasaran produk-produk } \\
\text { yang dihasilkan masyarakat } \\
\text { miskin agar tidak menjadi } \\
\text { korban eksploitasi } \\
\text { pedagang } \\
\text { perantara/tengkulak }\end{array}$ \\
\hline $\begin{array}{l}\text { Keluarga miskin cenderung } \\
\text { enggan beresiko (prinsip } \\
\text { safety first), sehingga } \\
\text { enggan untuk } \\
\text { mengembangkan usaha } \\
\text { alternatif yang dapat } \\
\text { memperkuat penyangga } \\
\text { ekonomi keluarga }\end{array}$ & $\begin{array}{l}\text { Pelatihan pendidikan } \\
\text { kewirausahaan bagi } \\
\text { masyarakat miskin. }\end{array}$ & $\begin{array}{c}\text { Meningkatkan etos } \\
\text { kewirausahaan masyarakat } \\
\text { miskin }\end{array}$ \\
\hline
\end{tabular}

Pemberdayaan pada intinya adalah pemanusiaan. Pemberdayaan, mengutamakan usaha sendiri dari orang yang diberdayakan untuk meraih keberdayaannya. Oleh karena itu, pemberdayaan sangat jauh dari konotasi ketergantungan. Dua hal yang menjadi prasyarat bagi upaya pemberdayaan adalah. Pertama, pembentukan kelompok (Pokmas) untuk memperkuat posisi bargaining penduduk miskin, khususnya dalam penentuan harga. Kedua, dalam bentuk pengembangan jaringan (networking) dan memperluas akses penduduk miskin terhadap pasar yang lebih luas. Pemberdayaan, harus diakui tidak bisa tumbuh dengan serta-merta dan semata hanya mengandalkan peran masyarakat miskin. Tetapi, melalui pendampingan yang tepat dan proses penyusunan program yang sejak awal melibatkan peran serta partisipasi aktif masyarakat miskin, niscaya yang tumbuh adalah sense of belonging dan keberdayaan masyarakat miskin dalam merespon program-program penanggulangan kemiskinan yang masuk ke wilayah sosialnya, sebagaimana tertera pada tabel 2 . 
Keenam, untuk mencegah agar keluarga miskin tidak menanggung beban akibat imbas kenaikan harga BBM, salah satu langkah antisipatif yang dibutuhkan adalah bagaimana membangun kohesi atau kelompok sosial yang solid di antara sesama keluarga miskin, entah itu dalam bentuk Pokmas, koperasi atau usaha bersama yang lain. Bagi masyarakat miskin, kohesi sosial yang kuat akan daat berperan sebagai jaring pengaman sekaligus bantalan untuk meningkatkan posisi bargaining mereka harus berhadapan dengan tekanan dari kelas sosial di atasnya.

Pembentukan Pokmas, koperasi dan lembaga keuangan mikro lain yang berasal dari dan untuk masyarakat miskin adalah salah satu bentuk perlindungan sekaligus pemberdayaan masyarakat miskin yang bertumpu pada potensi internal mereka sendiri. Studi ini telah membuktikan, akibat posisi tawar mereka yang lemah, sering terjadi keluarga miskin --yang notabene merupakan pelaku usaha mikro dan kecil-- terpaksa menjadi korban dominasi kelas sosial di atasnya, karena beban kenaikan harga BBM yang memperoleh kenaikan biaya produksi dan bahan baku, kemudian dialihkan menjadi beban penduduk miskin, antara lain dengan mengurangi jumlah upah kerja buruh miskin atau dengan cara tidak menambah biaya produksi dan biaya pembelian bahan baku produk di kalangan penduduk miskin yang bekerja pada orang lain melalui kerja borongan atau putting out system.

Ketujuh, dalam rangka memperkuat dan membantu menyediakan jaring pengaman bagi masyarakat miskin tatkala mereka menghadapi tekanan kebutuhan hidup, akan sangat membantu jika di masingmasing komunitas direvitalisasi peran lembaga-lembaga sosial-budaya masyarakat lokal yang fungsional dalam menjalankan peran sebagai patront subtitutif, yang fungsional untuk membantu dan melindungi masyarakat miskin. Seperti dikatakan James Scott, ketika masyarakat berubah makin kontraktual dan komersial, pola-pola hubungan sosial dan keberadaan lembaga sosial yang fungsional membantu masyarakat miskin umumnya telah makin memudar, dan tergantikan oleh pola-pola hubungan yang rasional-kontraktual.

Bagi masyarakat miskin, ketika mereka kehilangan lembaga-lembaga sosial yang bermanfaat seperti itu, tentu pilihan yang tersedia pada akhirnya tidaklah banyak. Di kalangan masyarakat miskin, sudah lazim terjadi mereka umumnya akan rawan masuk dalam pusaran kerja para pelepas uang yang seringkali menawarkan kewajiban pembayaran cicilan utang dengan suku bunga yang luar biasa tinggi, sehingga pelan-pelan mereka akan masuk dalam pusaran tekanan kemiskinan yang menyebabkan keluarga-keluarga miskin berpotensi kehilangan aset-aset produksi yang dimiliki. Untuk mencegah dan melawan dominasi para pelepas uang informal yang seringkali memanfaatkan situasi pasca kenaikan harga BBM, akan sangat bermanfaat jika di masyarakat dapat ditumbuhkan lembaga-lembaga sosial yang memiliki muatan sosial yang kental --yang bertindak sebagai bagian dari community suppoort system bagi masyarakat miskin. Peran Lembaga Keuangan Mikro, arisan simpan-pinjam, dan lain sebagainya yang dikelola dengan mempertimbangkan akar kultural, niscaya akan lebih fungsional membantu keluaarga miskin daripada cara kerja pelepas uang informal yang menetapkan bunga pinjaman yang mencekik leher.

Kedelapan, untuk membantu keluarga miskin memulihkan kembali kondisi ekonomi mereka, dan mendapat kesempatan untuk memperoleh tambahan penghasilan alternatif, akan lebih baik jika pengguliran dana program pembangunan infrastruktur dilakukan pasca kenaikan harga BBM. Pilihan moment pengguliran dana pasca kenaikan harga BBM ini dalam bentuk percepatan pembangunan infrastruktur di daerah ini, penting dilakukan untuk memperbesar pilihan dan perkembangan peluang usaha di kalangan penduduk miskin. Pengalaman telah banyak membuktikan bahwa pembangunan infrastruktur selalu menjadi roda penggerak sektor riil yang efektif, dan bermanfaat menciptakan tawaran lapangan kerja dan usaha baru bagi masyarakat miskin. Dengan memastikan masa pengguliran dana dan pembangunan infrastruktur yang tepat, maka diharapkan hasilnya akan dapat dinikmati masyarakat miskin yang membutuhkan tambahan penghasilan pasca kenaikan harga BBM. 


\section{Perekonomian Masyarakat Miskin Pasca Kenaikan Harga Bahan Bakar Minyak}

Dari hasil kajian yang telah dilakukan, beberapa temuan pokok kegiatan ini adalah sebagai berikut: Pertama, di Provinsi Jawa Timur, yang disebut keluarga miskin umumnya adalah keluarga yang secara sosial dan ekonomi terancam mengalami proses pendalaman kemiskinan dan rawan beresiko masuk dalam pusaran tekanan kebutuhan hidup yang makin tidak sebanding dengan penghasilan yang diperoleh. Bagi keluarga miskin (86,3\%), apalagi yang termasuk sangat miskin (13,7\%), efek domino dari kenaikan harga BBM, bukan hanya melahirkan problema dalam pemenuhan kebutuhan hidup sehari-hari, tetapi juga kelangsungan usaha yang mereka tekuni. Dari 600 keluarga miskin yang diteliti, sebanyak 37\% responden mengaku berpenghasilan antara 500 ribu hingga 1 juta, dan sebanyak $27,3 \%$ responden bahkan mengaku rata-rata penghasilan keluarga mereka per bulan tidak lebih dari 500 ribu. Studi ini menemukan, hanya 2,5\% responden yang berpenghasilan antara 1,7 juta hingga 2 juta per bulan. Sebanyak 12,5\% responden mengaku setiap bulan memiliki penghasilan sekitar 1,3 juta hingga 1,7 juta.

Kedua, pekerjaan yang ditekuni masyarakat miskin, sebagian besar merupakan usaha berskala mikro dan kecil. Dari 600 responden yang ada, hampir separuh mengaku bekerja sebagai petani dan buruh tani $(46,5 \%), 14,7 \%$ bekerja sebagai nelayan, $11,2 \%$ responden bekerja sebagai pedagang pasar, dan $10,8 \%$ responden bekerja di sektor industri kecil atau industri rumahan. Sebanyak $8,8 \%$ responden bekerja di sektor informal. Dengan latar belakang pendidikan yang relatif rendah, memang kemungkinan keluarga miskin untuk bisa diterima bekerja di sektor perekonomian firma nyaris tidak ada. Dengan memiliki latar belakang pendidikan hanya setara SD, tentu bisa dipahami jika sebagian besar responden pada akhirnya hanya bekerja sebagai buruh tani, pelaku usaha mikro dan kecil, dan lain sebagainya yang tidak menuntut persyaratan pendidikan yang tinggi.

Ketiga, di kalangan keluarga miskin, sudah lazim terjadi yang bekerja tidak hanya figur ayah sebagai kepala keluarga (75,84\%), tetapi juga kaum perempuan (42,7\%), dan bahkan tidak sedikit anak-anak juga harus ikut membantu bekerja mencari nafkah bagi keluarga orang tuanya. Dari 600 keluarga miskin yang diteliti, sebanyak $29 \%$ mengaku anak-anak mereka terpaksa ikut bekerja mencari nafkah untuk menambal kekurangan penghasilan orang tuanya.

Pada saat banyak keluarga miskin tidak menguasai ketranpilan alternatif dan tidak pula memiliki modal yang cukup untuk mengembangkan usaha alternatif, salah satu cara yang realistis mereka lakukan dalam rangka mencari tambahan penghasilan keluarga adalah dengan mengikutsertakan anak untuk mencari nafkah. Bahkan, sebagian keluarga miskin yang dikaji menyatakan anggota keluarga yang sudah lansia pun, jika perlu mereka juga bisa membantu untuk mencari nafkah dengan cara tetap bekerja walau pun usia mereka sudah tergolong senja. Sebanyak 7,7\% kakek dan 6,5\% nenek dilaporkan hingga studi ini dilakukan masih tetap bekerja untuk ikut membantu mencari nafkah bagi keluarga.

Keempat, efek domino kenaikan harga BBM sesungguhnya bukan hanya berdampak pada kelangsungan usaha atau kondisi perekonomian masyarakat, tetapi juga mempengaruhi kelangsungan hidup masyarakat, terutama keluaarga-keluarga miskin yang sehari-hari hidup dalam tekanan kebutuhan hidup yang cenderung naik pasca harga BBM naik. Dari 600 keluarga miskin yang diteliti, akibat-akibat yang mereka alami ketika pemerintah memutuskan menaikkan harga BBM bukan hanya mempengaruhi ketahanan ekonomi keluarga mereka, tetapi juga kondisi kerentanan dan kelangsungan hidup keluarga miskin. Studi ini menemukan, akibat kenaikan harga BBM, di lapangan yang terjadi adalah berbagai usaha yang ditekuni keluarga miskin mengalami kemunduran, modal menyusut, utang meningkat, sebagian terpaksa kehilangan pekerjaan, dan bahkan anak-anak terpaksa putus sekolah sebelum lulus di jenjang Pendidikan Dasar.

Kelima, mengencangkan ikat pinggang atau mencoba hidup dengan berhemat adalah salah satu cara yang populer dilakukan kelurga miskin agar mereka tetap dapat melangsungkan kehidupannya. Di kalangan keluarga miskin, studi ini menemukan bahwa cara penghematan yang paling sering dilakukan keluarga miskin untuk menghemat pengeluaran adalah dengan mengurangi kualitas menu 
makanan yang mereka konsumsi sehari-hari. Di luar mengurangi kualitas menu makanan, cara lain yang cukup banyak dilakukan keluarga miskin untuk menghemat pengeluaran adalah dengan mengurangi uang jajan kelaurga, terutama uang jajan ayah (48,3\%).

Keenam, imbas kenaikan harga BBM seringkali bukan hanya mempengaruhi kelangsungan hidup sehari-hari keluarga miskin, tetapi juga mempengaruhi kelangsungan dan kondisi usaha yang ditekuni masyarakat miskin. Meski pun pasca kenaikan harga BBM diakui sebagian besar responden bahwa keuntungan dan pangsa pasar meningkat, tetapi kebutuhan akan modal dan biaya produksi juga meningkat, sehingga ujung-ujungnya margin keuntungan yang diperoleh pun hanya secara absolut meningkat, namun nilai tukarnya untuk dipergunakan membeli barang-barang kebutuhan hidup yang lain bukan tidak mungkin malah menurun.

Ketujuh, kenaikan harga BBM bagi masyarakat miskin seringkali melahirkan sejumlah dilema. Di satu sisi, masyarakat miskin menyadari bahwa pasca kenaikan harga BBM, harga bahan baku dan harga barang kebutuhan lain-lain meningkat, yang implikasinya mereka seharusnya juga meningkatkan harga jual produk mereka. Tetapi, di sisi yang lain, ketika mereka memutuskan menaikan harga komoditi yang mereka hasilkan, bukan tidak mungkin komoditi yang mereka hasilkan akan kehilangan sebagian pembelinya.

Kedelapan, di tengah iklim persaingan yang makin ketat, banyak responden mengaku memang tidak mudah untuk mempertahankan, apalagi membesarkan usaha yang mereka tekuni. Ada berbagai kendala yang menghambat peluang keluarga miskin untuk mengembangkan usaha atau pekerjaan yang mereka tekuni. Pertama, adalah kurangnya akses responden pada jaringan pemasaran produk yang mereka hasilkan. Kedua, karena keterbatasan modal yang dimiliki. Ketiga, karena iklim persaingan yang makin ketat. Di daerah sentra komoditi tertentu, studi ini menemukan seringkali penduduk lokal mengeluh karena menjadi korban iklim persaingan di antara sesama orang yang memiliki pekerjaan dan komoditi yang sama. Pihak pedagang perantara, justru lebih berpeluang mengambil keuntungan dari situasi pasar yang oligopsoni --jumlah pembeli lebih sedikit dari jumlah penjual.

Kesembilan, dari 600 keluarga miskin yang diteliti sebagian besar responden $(83,8 \%)$ mengaku menerima margin keuntungan sangat kecil, hanya di bawah $10 \%$. Berbeda dengan para majikan yang memiliki kekuasaan untuk tetap menekan upah buruh dan mengalihkan beban kenaikan harga bahan baku kepada responden --yang notabene adalah pelaku usaha mikro dan kecil-- sebagian besar responden mengaku posisi bargaining mereka lemah, alias tidak berdaya, sehingga dalam penentuan harga maupun margin keuntungan, umumnya merekam nejadi pihak yang paling dirugikan. Dalam mata rantai perdagangan, pihak yang paling dominan dalam menentukan harga jual kkomoditi yang dihasilkan masyarakat miskin umumnya adalah pedagang perantara $(50 \%)$ atau majikan tempat responden bekerja $(20,7 \%)$.

Kesepuluh, mekanisme yang seringkali dikembangkan keluarga miskin untuk memenuhi kebutuhan hidup pasca kenaikan harga BBM adalah dengan cara utang dan meminta bantuan kerabat --yang merupakan jaring pengaman sosial bagi keluarga miskin di saat mereka mengalami situasi krisis. Sedangkan usaha yang dilakukan keluarga miskin untuk menyiasati tekanan kemiskinan selain mengembangkan perilaku subsistensi, melakukan dan pengetatan pengleuaran, seringkali juga dengan cara mendayagunakan anggota keluarga untuk ikut mencari nafkah bagi keluarga. Usaha seperti melakukan diversifikasi usaha, dalam pandangan keluarga miskin sangat sulit dilakukan, dan peluang untuk terus meminta bantuan kerabat juga disadari makin lama makin sulit.

Kesebelas, peluang keluarga miskin untuk mengembangkan usaha alternatif umumnya kecil, karena selain tidak memiliki modal yang cukup $(80,8 \%)$, juga karena sebagian besar keluarga miskin umumnya tidak memiliki asset yang memadai. Tidak banyak keluarga miskin yang memiliki lahan garapan atau perahu yang bisa dimanfaatkan untuk mencari nafkah di laut $(60,8 \%)$. 
Keduabelas, bantuan yang dibutuhkan keluarga miskin, sebagian besar adalah bantuan permodalan $(69,3 \%)$, bantuan di bidang pemasaran komoditi yang mereka hasilkan $(61,3 \%)$, dan bantuan dalam bentuk teknologi atau peralatan produksi yang bisa mereka manfaatkan untuk mendukung usaha yang ditekuni.

\section{Simpulan}

Imbas kenaikan harga BBM, seringkali bukan hanya mempengaruhi kelangsungan hidup sehari-hari keluarga miskin, tetapi juga mempengaruhi kelangsungan dan kondisi usaha yang ditekuni masyarakat miskin. Kenaikan harga BBM, bagi masyarakat miskin juga seringkali melahirkan sejumlah dilema. Di satu sisi, masyarakat miskin menyadari bahwa pasca kenaikan harga BBM, harga bahan baku dan harga barang kebutuhan lain-lain meningkat, yang implikasinya mereka seharusnya juga meningkatkan harga jual produk mereka. Tetapi, di sisi yang lain, ketika mereka memutuskan menaikan harga komoditi yang mereka hasilkan, bukan tidak mungkin komoditi yang mereka hasilkan akan kehilangan sebagian pembelinya

Kerena itu, kebijakan exit strategy yang perlu dikembangkan menghadapi dampak kenaikan harga BBM adalah bagaimana mendorong pengembangan ekonomi pedesaan dan sektor pertanian agar tetap dapat menjadi tempat bersandar bagi keluarga miskin meski terkena imbas efek domino kenaikan harga BBM. Bantuan dan program yang digulirkan pemerintah di sini seyogyanya tidak hanya berupa bantuan modal usaha bagi petani miskin, tetapi yang lebih penting justru adalah bantuan dalam bentuk satuan biaya produksi, seperti pupuk dan bantuan dalam bentuk asset produktif yang bermanfaat memperbesar margin pembangian keuntungan yang mereka peroleh. Kelebihan program penanggulangan berbasis aset adalah bantuan yang disalurkan tidak akan habis, tetapi akan tetap berkelanjutan dan dapat sekaligus memperkuat posisi bargaining penduduk miskin.

\section{Daftar Pustaka}

Alliyah (2013) Efektivitas Bantuan Langsung Sementara Masyarakat sebagai Kompensasi Kenaikan Harga Bahan Bakar Minyak Tahun 2013 bagi Rakyat Miskin. Potensio 19(1).

Fauziyah D (2003) Dampak Kenaikan Harga Bahan Bakar Minyak terhadap Pendapatan Usaha Nelayan Gill Net dan Rawai di Pelabuhan Perikanan Nusantara Palabuhanratu, Sukabumi, Jawa Barat.Skripsi. Bogor: Program Studi Manajemen Bisnis dan Ekonomi Perikanan Kelautan, Jurusan Sosial Ekonomi Perikanan dan Kelautan, Fakultas Perikanan dan Ilmu Kelautan. Institut Pertanian Bogor.

Hasyim I (2005) Bunga Rampai : Subsidi BBM dari Dulu hingga Sekarang. Jakarta: Pertamina.

Iqbal, H (2008) Implementasi Kebijakan Program Bantuan Langsung Tunai Tahun 2008 di Kabupaten Kudus. Tesis: Program Pascasarjana Universitas Diponegoro Program Studi Magister Ilmu Administrasi Konsentrasi Magister Administrasi Publik.

Junaidi (2013) Implementasi Kebijakan Program Bantuan Langsung Tunai (BLT) Tahun 2008 di Kabupaten Aceh Timur. Pemerintah Kabupaten Aceh Timur dan Universitas Sumatera Utara (USU) Medan 3(1).

Pasaribu L (2008) Dampak Kenaikan Harga BBM (Solar) terhadap Usaha Penangkapan Ikan dengan Pukat Cincin. Skripsi. Medan: Program Studi Agribisnis, Departemen Sosial Ekonomi Pertanian, Fakultas Pertanian. Universitas Sumatera Utara.

SMERU (2011). Kajian Cepat Pelaksanaan Program Bantuan Langsung Tunai (BLT) 2008 dan Evaluasi Penerima Program BLT 2005 di Indonesia. Jakarta: Lembaga Penelitian SMERU.

Suryawati SH, Andrian R, Achmad Z \& Agus HP (2013) Kebijakan Antisipatif dalam Menghadapi Dinamika Harga BBM pada Usaha Perikanan Tangkap. Jurnal Kebijakan Sosek KP 3(2).

Suwitri S (2008) Konsep Dasar Kebijakan Publik. Semarang: Badan Penerbit Universitas Diponegoro. Yusgiantoro P (2000) Ekonomi Energi, Teori dan Praktik. Jakarta: Pustaka Lembaga Penelitian, Pengkajian, dan Pengembangan Ekonomi dan Sosial. 